\title{
Roma Youth Between Traditional Education and Current Occupations
}

\author{
Diana-Maria Hulea ${ }^{*}$ \\ 1 University of Bucharest, Department of Sociology, 9 Schitu Măgureanu, 010181 Bucharest, Romania
}

KEYWORDS

Education

Roma

Family

Employment

Tradition
ABSTRACT

Traditionally, in the Roma family, the woman is responsible for educating the children, from birth to marriage. Thus, she has an educational role of prime importance that helps to ensure the group's survival, along with its characteristics and traditions. The father teaches his sons the traditional craft.

The main purpose of this article is to present aspects of the traditional education provided by the Roma family and to explain the Roma attitude towards school, but also to explain the relationship between traditional education and current occupation of Roma young people. The data collection method used was the semi-structured interviews on 42 people, both from rural and urban areas.

It was found that the traditional Roma family provides continuing education based on mutual respect between children and adults without a division between theoretical education and the apprenticeship of roles in the family. The family also provides the economic discipleship, as the child learns ways to support his family. It was noted that for Roma living in urban and rural areas, schooling is not particularly important. However it was also noted that they have changed their way of thinking to some extent, because they realize that it is very important to know how to read and write. Regarding the current occupations it can be argued that, in general, Roma young people develop economic activities that imply some degree of independence. We observe an attitude of rejection towards income-generating activities that involve compliance with a fixed schedule, inclusion in a group of colleagues and strict conditions in the workplace.

* Contact address: diana.hulea@yahoo.com (D. Hulea). 


\section{The Background Research}

Earlier research attempted to capture the characteristics of the Roma family between tradition and modern times. In that research aspects of formal and informal education were considered; issues that we intend to consider in this paper.

It is specifically argued that formal education includes (Vaideanu 1988: 23):

- Development of teaching in specialized institutions;

- Clearly stated educational objectives;

- Specialized teachers;

- Systematized knowledge: timetables, curricula, textbooks;

- Correlation between directed and independent learning;

- Learning stages, chronologically ordered;

- Evaluation of certain stages of schooling.

Non-formal education means:

- All educational influences that take place outside the classroom;

- An educational reality that is not formalized, but has formative effects;

- Specialists who coordinate the activities have a more discreet role, assuming the task of moderators (Vaideanu 1988: 231).

Informal education is concerned with:

- Spontaneous nature of education free of any formality;

- An acquisition of knowledge gained by the person in a random manner;

- Learning achieved in different circumstances with low processing, in a manner that is not structured and planned;

- 'Summarizing of human experience' (Shane 1980: 484, apud. Cozma 1994: 274).

As a permanent dimension of human existence, education must have a global character, effectively conjugating the formal education with the nonformal and informal education. According to the holistic approach (Ph. Coombs, P. Lengrand and Th. La Belle) the boundaries between the three types of education are theoretical, with opportunities for interpenetration and interdependence:

'In practice, the informal, formal and non-formal education must be seen rather as predominant modes of learning than as entities. As a 
means of emphasizing the formal, non-formal and informal education can exist simultaneously, sometimes in agreement, sometimes in contradiction.' (La Belle 1982: 162, apud. Cozma 1994: 276).

We consider that the formal education is classroom-based, provided by trained teachers. Informal education happens outside the classroom, after-school, in community-based organizations, museums, libraries, or is provided at home by the family or by the entire community. For example, in the Roma case, the entire community contributes to the education of all the children of different ages. The community transmits the roles in the family, group and society.

We consider that our study is compatible with a qualitative approach, aiming to 'describe and explain the realities by the group itself' (Ilut, 1997: 38). The unit of analysis in the present research is the family. The sample used is divided into two groups of subjects, from rural and urban areas, which in turn are divided into two categories according to whether the group belongs to the former nomadic people or to the sedentary people. The families belonging to the former nomadic group lived in tents until 40-50 years ago and travelled from place to place. 42 people were selected. Since families are structured in particular ways, their members can be subdivided according to certain criteria: age, sex, place of residence, group affiliation, position in family and in the community. That is why the people interviewed were both male and female, from both rural and urban areas, descendents of both the sedentary and the former nomadic people, ranging in age from 20 to 77 years old with some being considered by the community members as having the status of leaders.

The study took into account the extended family and included:

- In the urban areas, respectively the city of Sibiu:

- 3 Roma families - silk Roma;

- 2 Roma families - coppersmiths.

- In the rural areas, residents from the following villages were included:

- Porumbacu de Sus - 2 Roma families of coppersmiths;

- Alțâna - a family of coppersmiths;

- Ighişu Vechi - a family of coppersmiths;

- Merghindeal - a family of coppersmiths; 
- Brateiu - 3 families of coppersmiths;

- Fofeldea - 2 Roma families of Roma woodworkers.

Referring to the aspects presented above we must mention the following details: silk Roma and Roma woodworkers are sedentary people and coppersmiths are the former nomadic people. We intentionally included in our sample more families belonging to the Roma descendents of the formerly nomadic people than sedentary, because we want to study the habits and traditions of Roma, aspects that we encounter to a greater extent in that group. This choice is supported by the work of Viorel Achim (1998: 59). The author states that the nomadic Roma were the people who have best preserved the specifics of the Roma population, until the present times. Due to many factors, starting with their own type of habitat, the impact of the main society on the Roma nomadic people was much lower than for the other Roma.

Silk Roma are the sedentary Roma living in Transylvania. They deal with marketing silk and carpets. Their name comes from their manners, manners that are more elegant (compared to those of other Roma that were working the fields) and are a result of their long trips abroad and the contacts with customers who came from a more stylish world (Burtea 2002: 68). Another sedentary people who were included in our analysis are represented by the woodworkers. They deal with soft hazel wood, locust, linden, poplar, willow and alder in the manufacture of baskets, brooms, crates, pails, forks, spindles, reels, spoons, bowls, chests, trunks, rakes, clothes hangers and cassettes. The last group of Roma included in this study is the former nomadic group of coppersmiths. Roma coppersmiths are scattered in the Oltenia area: Vâlcea, Dolj, Olt, Gorj and Mehedinți, and in Transylvania, in Sibiu and Alba Iulia. They deal with the making of pots, kettles, cheese trays, pans, ladles, stills, or religious ornaments, candlesticks, trays, tin cups made of copper or stainless steel. The coppersmiths were nomads for a long period of time, lived in tents and used copper or brass as the main working material. Coppersmiths still retain their defining customs, language and costume.

The data collection method used was the semi-structured interview. Thus, to conduct semi directive discussions, the interviewer has a series of questions that serve as a guide and he does not ask them in a strict order, 
but depends on the conversational flow and on the reactions of the participant (Moscovici and Buschini 2007: 213). This research method brings the following advantages: the environment created during the interview is not a rigid one; the interviewed person describes and explains in an open manner the realities of the group. So, as we described above, the analysis included a total of 15 extended families of silk Roma, coppersmiths and woodworkers from the urban and the rural areas and, in the actual interview, the questions were answered by one or more adult family members. 42 people were directly involved in the study.

\section{The Current Situation of the Roma Population in Romania in Terms of Schooling and Employment}

The Roma population, after the fall of communism, was severely affected by the failure to secure a job, the reduction of social benefits and the disappearance of state support for large and poor families. The Roma were among the first groups to be made redundant due to low skills with unemployment rates in this population reaching high rates. The World Bank Report 'Poverty Monitoring Analytical and Advisory Assistance Program, Romania, 2007', states that in 2006, Roma were 4 times more likely to be found among the poor than the rest of the population. The Roma population suffers from higher than average rates of unemployment, poor housing conditions, poor health and a relatively high rate of illiteracy. Belonging to the Roma population remains a significant determinant of poverty risk. It was observed in 2006 an even stronger negative association between being Roma and welfare: if in 2003 the consumption per equivalent adult of a Roma household was 18 percent lower than that of a non-Roma, in 2006 the corresponding figure is 20 percent. For the Roma households living in rural areas the situation is even worse.

The research conducted by Research Institute for the Quality of Life noted that in 1992, a total of $23.4 \%$ of economically active Roma persons, were employed. In 1998, the number dropped to $12.9 \%$. Employment of the Roma population in Romania is much lower than the national population (47\% versus $61.7 \%)$. 
Once the Agricultural Production Cooperatives were closed many Roma living in villages were left without the opportunity to earn a living. According to the Land Law application, most of them did not posses any land before the collectivization and were excluded from the assignment (Law no. 112/1991). Some of these Roma were forced to go elsewhere in search of living resources, to the big cities or abroad (Achim 1998). It is expected that Roma, deprived of the skills demanded by the market and deprived of school education and capital, will become increasingly marginalized, and thereby become the most vulnerable segment of population in Romania.

The Barometer of Ethnic Relations conducted in the period 1994-2002 (Bădescu, Kivu and Robotin 2005) shows that the problems of the Roma population are numerous and include all aspects of life, not just those related to preservation of ethnic identity, but also discrimination, difficult access to health care, unemployment, illiteracy and poverty.

At the beginning of the transition, Roma were in an unfavourable position, mainly due to lower educational levels. A study made by Yale University in 2001 indicates that many Roma are working without a contract of employment (25\% of the Roma population in the sample, compared to $5 \%$ of non-Roma population), reflecting the significant presence of Roma labour 'black market' (Sandu 2005: 10).

The World Bank Report nr. 22180-RO states that poverty among Roma is linked to a number of factors that correlate with each other. The level of education is low compared to other population groups, and data from recent surveys show that these differences are increasing. The percentage of Roma population without basic education (grades 1-8) increased from 36\% in 1994 to $48 \%$ in 1998 . As a result the Roma were among the first to have been unemployed at the beginning of restructuring and have encountered significant obstacles in the process of reintegration since then.

The Roma Inclusion Barometer, conducted in 2007, highlighted the low level of formal education that the Roma population as compared to the non-Roma. Thus, $48 \%$ of non-Roma families have children aged 0-6 years who are not attending nursery school or kindergarten, compared with $80 \%$ of the Roma families in Romania that are in the same situation. For the children aged 7-11 years, $19 \%$ of them do not go to school in the case of 
Roma subjects, compared to $2 \%$ in the case of non-Roma subjects. For the children over the age of 11 who do not attend school, the percentages are $39 \%$ for the Roma families and 9\% for the non-Roma families.

The monitoring report 'Equal access to quality education for Roma' produced by the Open Society Institute in 2007 shows that the percentage of Roma who have not benefited at all from school education (according to the census made in 2002) is 34.2\% compared with 5.5\% appropriate proportion of the majority population. The same study shows that $29 \%$ of Roma have graduated high school compared with $64 \%$ of the majority population.

The low levels of education and the poor quality education, in the case of the Roma population, supports the reproduction of social inequality through schooling. The lower social classes, among which are most of the Roma, cannot afford higher education levels for their children, thus we are witnessing a process of social reproduction of educational inequality and, more broadly, the cultural reproduction of inequality. The low levels of education in the case of Roma are generally directly related to a low level of employment, occupations devalued in society and, consequently, low incomes. Furthermore, studies have shown that for the same level of education, the Roma have lower incomes than the general population (Surdu 2010: 60-61).

As a consequence of the poor schooling of Roma, the level of employment and the income earned are also reduced. According to the Roma Inclusion Barometer conducted in 2007, Roma in Romania feel most strongly discriminated when they are looking for a job.

\section{The Educational Function within the Roma Family}

Using experience gained over a period of 24 years as head of the Research Centre for Gypsy, founded in 1979, Professor Jean-Pierre Liégeois (2008: 63) concluded that in Roma's life everything revolves around his family, the basic unit of social organization, system of family groups, economic unit, educational unit that ensures social reproduction and security and protection of the individual. The family offers an element of permanence, synonymous with stability. 
In the traditional Roma family the woman is obligated to take care of the children, to wash them, to cook for them, to educate them and to teach them Roma language. She teaches her daughters to sew, wash, cook and prepares them for the life of married women. The father teaches his sons the traditional trade. For example in the village of Brateiu the young coppersmiths' boys have a little hammer and an anvil and learn how to make buckets and boilers from a young age.

The mother imposes rules and sanctions that are inherited, maintains discipline in the family and has specific expectations regarding the behaviour of the children. She is the leader of the household and is responsible for the upbringing, care and education of the children. It can be argued that she is the conservative element in the social group because she is able to reproduce traditions. For this reason, she may also be part of the change. Being the one that educates the children, she is also the one that transmits the costumes and traditions of the group, but all of them are filtered through her life experience and her own believes. The traditional father is inflexible. He imposes taboos, and he assures the moral and financial support for the family. He imposes respect and gives advice to his children because he is considered to be always right and, because of that, he has the last word on any issue. He decides on the general orientation in life of his children, including their marriage (Grigore 2001).

In the case of Roma coppersmiths, from the rural and the urban areas, who have been the subject of this study, the father is the head of the family, and as such has the authority and power of decision. He has an important economic role and also serves as the transmitter of the traditional craft to his sons. The mother has an obligation to ensure and supervise the education of the daughters in the family and if the daughter is not a virgin when she gets married the mother is blamed because it is considered that she was unable to provide a proper education for her daughter:

The mother's traditional tasks are those related to raising and educating children. She makes recommendations on educating children and the husband makes decisions. Instead she is directly responsible for raising girls, in particular. From a certain age, the boys are taken by the father, who will teach them the art trade. Instead, the girls are trained from early childhood to become housewives by their mothers. The mother shows them: look here, how to make food, look here what the man will 
expect for you to do. And besides that the mother should ensure that the bride is a maid in the wedding night, because if she did not care about this, the shame will fall on her. There have been cases in which the mother and her daughter were banished from the house. The father said: $a$, you are to blame. And that man married another wife, who knew how to grow up a decent girl. (Male, 40, coppersmith, Sibiu).

Traditionally, the birth of the first child is the act that founds the family. It will be followed by further children, large families aren't unusual, but generally, the child is welcomed. The education of the child is provided by the whole family. He lives among three or four generations, and his socialization takes place in a group that provides cohesion, coherence, continuity and security. Generations are not opposed to each other. They form a whole world and there is no separation between the child and the adult world. They are always in physical contact and social contact, protecting each other from the outside, never left alone and well surrounded. They work together, live together and suffer together. The child respects the adult and he is respected. The child is encouraged to develop exploratory behaviour in his environment (for example looking for metal, sorting the collection, sale). Experience, initiative and responsibility are valued in a flexible environment, with no strict hours or unnecessary constraints. But freedom of initiative is not synonymous with lack of control. Simply, there is no direct or individual control or orders involving a lot of listening. The control is global, the control of the group. It is about an education towards independence, not about indifference. Behaviours are channelled to promote autonomy and gain the respect of the group (Liégeois 2008: 64-65).

Traditionally, the Roma family is not only a sum (in an arithmetic sense) of individuals. It is a whole, an ensemble of members in solidarity with other families and in solidarity against strangers. Conflicts are experienced collectively: the relationships between individuals are relationships between family groups; the individual is acting as a member of his family. A mistake of the individual is considered to be a mistake for the family. A positive act strengthens the prestige of the entire family. A welleducated child honours his family until he is married. After marriage, if a male changes his family groups, he will continue, in the group that receives him, to represent the group of origin. 
Despite the traditional values of Roma, which revolve around the concept of family, Romanian sociologists (Zamfir and Zamfir 1993) observed that at present, in Romania, cohesion and solidarity within the Roma family are at relativity low levels. The Roma, especially the girls (the average age of the wife at the first marriage is 17 years versus 22-25 years as it is for the entire population), get married at an early age as do the boys. The tradition of marriages not being conducted by the authorities is still largely followed. Romanian researchers consider that it becomes a powerful factor in decreasing both family cohesion and sustainability, and responsibility towards children. Roma families are characterized by a large number of children, at least double that of the families of the majority. The large number of children worsens the financial situation of the family. Abandonment of children in the nursery or a paediatric hospital, or placing them in a care institution, is relatively common within the Roma population. High birth rate is one of the most pressing issues facing this population. This is a problem that we encounter especially with the sedentary Roma families that we analyzed in this study.

Analyzing the number of children that are born in a family we can observe the following:

Table 1. Number of children in Roma families from Sibiu county

\begin{tabular}{|c|c|c|c|c|}
\hline \multirow{2}{*}{\begin{tabular}{c} 
Number $\begin{array}{c}\text { of } \\
\text { of } \\
\text { children }\end{array}$ \\
\cline { 2 - 5 }
\end{tabular}} & COPPERSMITHS & SILK ROMA & COPPERSMITHS & WOODWORKERS \\
\hline 1 & $30.0 \%$ & - & $42.3 \%$ & $26.6 \%$ \\
\hline 2 & $50.0 \%$ & $44.4 \%$ & $20.0 \%$ & $13.3 \%$ \\
\hline 3 & $10.0 \%$ & $11.1 \%$ & $20.6 \%$ & $6.6 \%$ \\
\hline 4 & $10.0 \%$ & $11.1 \%$ & $13.5 \%$ & $20.0 \%$ \\
\hline 5 & - & $22.2 \%$ & $1.6 \%$ & $26.9 \%$ \\
\hline$>5$ & - & $11.2 \%$ & - & $6.6 \%$ \\
\hline
\end{tabular}

Note: Data are presented as percentages. These are data obtained in the wider research which I have previously mentioned.

From the table above we can see that $80 \%$ of the coppersmith families from urban area have one or two children.

In our families of Roma coppersmiths you will find 2 or 3 children, so normal families. (Male, 40, coppersmith, Sibiu). 
For the silk Roma who live in the urban areas, 55.5\% of them have two or three children, and $33.4 \%$ have five or more children. Compared with the Roma coppersmiths from the urban areas, we notice that the silk Roma families have more children. In rural areas, $62.3 \%$ of Roma coppersmith families have one or two children and $34.1 \%$ have three or four children. Regarding the woodworkers Roma, 39, 9\% of them have one or two children, and $33,5 \%$ have five or more than five children.

I have only one child, because you know that is hard in this life with many children. (Female, 21, woodworker, Fofeldea).

I have 11 children, seven girls and three boys. With my first wife first I had four children and I divorced. (Male, 65, woodworker, Fofeldea).

In general, it is noted that Roma families who are sedentary peoples have a greater number of children than Roma families who are formerly nomadic peoples.

In our study we identified families in which there are cases of abandoned children. We only encountered this situation for the silk Roma that live in the city of Sibiu. Using the table below we analyze nuclear families and the situation of their children.

Table 2. Number of abandoned children in silk Roma families

\begin{tabular}{|c|c|}
\hline \multicolumn{2}{|c|}{ SILK ROMA FROM THE URBAN AREA } \\
\hline NUMBER OF CHILDREN IN THE FAMILY & ABANDONED \\
\hline 2 & 1 \\
\hline 4 & 2 \\
\hline 2 & 2 \\
\hline 12 & 1 \\
\hline 3 & 1 \\
\hline 2 & 1 \\
\hline 2 & 1 \\
\hline
\end{tabular}

Note: Data are presented as numbers. These are data obtained in the wider research previously mentioned.

For all these children who are separated from their families a special protection measure was set up, according to the Law no. 272/2004 on the protection and promotion of the child's rights. The special protection measure means the placing of the child in the care of a substitute family for a 
period of time. Meanwhile, the state tries to support the birth families, in order for them to be able to receive their children back.

In the case of the Roma coppersmith families who live in the urban and rural areas and the Roma woodworkers who live in the rural areas that we interviewed, we have not identified cases of abandoned children:

At least at these Roma of ours, that are nomadic coppersmiths there are no such things. So you will not find the children of the nomadic and coppersmiths Roma in care institutions, unless they have severe handicaps and then they are not able to raise them properly. Even if families are poor, they keep their children. When we discus about abandoned children we can refer to these Roma that I told you about, woodworkers, these silk Roma forgot any Roma traditions. They have children; they do not think about where they will live, that they live 5 persons in one room. But they should think about the possibilities that they have to raise their children. And there are many families like that. They are the majority, not us. They are Roma but they do not speak Romany language. (Male, 40, coppersmith, Sibiu).

Due to greater instability among Roma families, many Roma children live in single parent families, being cared for only by the mother. For many children, the father has never lived with them, because he got married again, or is away from home for long periods of time. Such families are dealing with increased responsibilities for children, resulting in primary socialization problems, particularly non-acceptance of authority (which usually is provided in the family by the father). In environments where there are delinquent adults, some Roma children learn from early childhood to steal, beg or cheat (Preda 1999).

\section{Roma Attitude towards School}

Regarding formal education, Cătălin Zamfir (1993) considers that for the Roma traditional way of life, the school is not relevant. The school represents a way out of the community, a way for the Roma population to be absorbed by the majority of non-Roma population.

For Roma, the school as a foreign element aimed at educating children, is considered to be harmful, since it attempts to overthrow the family education. Parents often have a poor memory about school - when they attended it - and are reluctant to entrust their children to this institution. 
Even more, they see that in life, until now, their children are doing just as well as those who attend school and that there is no obvious link between educational achievement and social or economic success (Liégeois 2008: 66).

From the present research we noticed that, indeed, for Roma living in urban and rural areas, schooling is not viewed as being particularly important, but there is some emerging evidence that suggests that this way of thinking is changing because they realize that it is very important to know how to read and write:

I said that I will allow the child go to school until the eighth grade, until he can go to school here in our village. And if he wants to continue school, we will see. Few think so, but they can say anything to me; nobody can make me change my mind because I don't know how to read and write and it is very difficult for me. And then I decided to allow the child to graduate the school in our village. (Female, 33, coppersmith, Porumbacu de Sus).

The Roma coppersmiths from the city of Sibiu are more influenced by the majority of the population than those in rural areas. To support this claim we note from the field data that there are coppersmith families in the city of Sibiu who had hired tutors for their children, both boys and girls.

Vasile Burtea (2002: 98) says that coppersmith girls marry young and usually do not attend school, because it is thought that school perverts. School is considered to be a place of temptation and aggressions from strangers, issues that can lead to the loss of virginity and to the loss of any prestige in the community. These fears and reasons for the girls not to attend school are raised even today. The Roma coppersmiths who live in the rural areas who participated in the interview talk about the habit of stealing the beautiful girls who attend school in order to marry them and form a new family.

In Ceauşescu's period they used to send us to school. Now who wants to go, goes to school, who does not want to go, stays at home. And they will have no education at all. And this is a fact that I do not approve of. I do not like this, because it is very good to know how to read and write. I would love my children to know how to read and write. But we have problems in our village because they shut down the school, and opened instead a nursing home for old people. And we cannot allow for the girl to go to school in the village of Bârgiş, because someone might steal them. Already some guys from the village of Porumbacu stole a girl form the village of Băieşti. And the child protection institution is 
involved in this case. The girl is very beautiful, but she is only 12 years old, and the boy is around 20 years old. And if the boy steals the girl, he takes her to his home, and there will not be an agreement between families anymore, as it should be. But after a while we have to go and talk to the boy who stole the girl, and the scandal begins. The boy hides the girl and her family will not find her. Once the boy slept with the girl, he made her a woman, you have to make an agreement with him, whether you like it or not. And then the girl does not receive her dowry anymore. Because the boy that stole her might be from a poor family, and we do not like this. And the girl remains married to the boy that stole her. (Female, 49, coppersmith, Ighişu Vechi).

As we can see, school attendance in rural areas depends not only on the willingness of Roma families to send their children to school, but also on the local context. In most villages there are primary schools, but the secondary school children must go to the main village in the area and if they want to continue attending high school or vocational school children must travel to the nearest town. The Roma access to school is made more difficult by the merging of schools. Even if there are school buses available for children in rural areas, Roma families do not accept this solution, especially when it comes to girls. Girls are not allowed to go to another village, unless they are accompanied by their mothers, a situation that is impossible, as a mother cannot go to school everyday with her daughter and stay until the classes end.

The level of schooling in the interviewed families is, on average, between two and eight years:

Now children go to school until they are married, until the eighth grade. My children went to school for eight years and a quarter. The same is for the girl; they go to school until they learn how to write. Now the times when a person had no ID, had nothing and was not registered anywhere are gone. In old times, Roma used to travel in a wagon from village to village, nobody used to ask them anything, and they knew he was a coppersmith and that he wanted to stay outside the village and work. (Male, 60, coppersmith, Brateiu).

Educated in fear of foreigners, fear maintained and justified by the conflicting situations, the child has an attitude of opposition towards the school, considered to be a foreign institution. He is not prepared by his education to take orders or to accept arbitrary rules. He will not understand some of the rules that the school enforces: for example, to be separated from 
his brothers and sisters for reasons of age, to not be able to express immediately and with passion his feelings, and to abandon any familiar initiative. For example, the Roma children are not used to so many strict rules, as: speak only when you are asked, stay in your place, ask permission if you want to do or say something, etc. In the face of such contradictions between the two educational systems and plunged into an alien environment, the child, if the school does not make a profound effort to adapt, will be nervous and anxious, aggressive towards people and objects. Even more, the school builds the skills and habits of others and the child is not prepared to deal with linguistic structural differences. All this helps to support a dominate view of the child as being socially and sometimes even mentally inadequate (Liégeois 2008: 66).

\section{Traditional Crafts and Present Occupations of Roma Young People}

The continuation of traditional crafts is an important issue for Roma, as Roma families were built around the traditional crafts practised by a certain group members and transmitted from father to son.

Now, in general, the economic activities of Roma are extremely diverse and highly variable. That means that they can change over time. Jean-Pierre Liégeois (2008: 70) gives some examples of trends. Traditionally exercised and expanded activities can be located almost everywhere: working with metals (tin, boiler making, gilding, forging, etc.), recovery of various metals and sale, horse trade, show crafts and circus performance (musicians, acrobats, jugglers, dancers, storytellers, comedians, magicians, etc.) holiday related (itinerant traders), itinerant or sales markets (fruit, vegetables, curiosities, carpets, textiles, clothing, miscellaneous items at reduced prices, etc.) manufacture and sale of various items (violins, jewellery, belts, tablecloths, lace, wicker items, wooden and metal), sometimes agricultural work, often seasonal (harvest in particular), guessing. However there are some activities that have tended to disappear: sharpening tools, manufacture of umbrellas, wrought iron objects or wood, although sometimes such activities may be revived. There are also those that are expanding: trading used cars, trading old objects (curiosities), certain performance-related jobs, seasonal jobs in construction or maintenance work. 
Traditionally, coppersmiths living in the rural and urban area of Sibiu, made buckets, kettles, pot, trays, pans, ladles, stills, or religious ornaments, candlesticks, cups of copper or brass or stainless steel. The study conducted noted that in most families, only old man still know the secrets of the traditional craft, practiced occasionally on request. Currently young coppersmiths living in urban area are business people, even if they have learned the traditional craft:

My grandpa, my dad and my uncles used to make boilers, and sale them here in Transylvania. Mom has some photos. They used to load a truck full of large and small boilers; they had many orders and they used to come here in Transylvania and in Baia Mare. Lord when I saw how many boilers. But special boilers, you know, they were sparkling, looking so good and polished. But you should know that they made a lot of money. (Female, 25, coppersmith, Sibiu).

Our parents and grandparents are the ones who lived in tents and worked with copper, making boilers and buckets. This was the habit from the past and almost until our generation. They used to work with copper when I was a child. I also learned the secrets of the traditional craft; I could practice it; I used to work when I was young. Today we no longer practice the traditional craft, but we remained in the non-ferrous metals aerie, so if the ones before us were processed nonferrous metals, we are also processing nonferrous metals but with the technology of the XXI century. We are making products of copper, we do not make boilers anymore, but we produce bronze bars and all kinds of industrial products. (Male, 40, coppersmith, Sibiu).

In rural areas young Roma coppersmiths breed animals and sell them, work the land or deal with the trade of objects or products. In more recent times they have gone abroad, where they earn money by begging. The coppersmiths in rural areas, who were included in the present research admit that many of the young people travel abroad regularly to beg for money.

Researchers have noted that Roma, in general, do not claim rights, do not assert competitive capacities, but they require acceptance, help generated by the felling of compassion and pity and the acceptance of moderate deviance. We believe that this last aspect is due to the way they have managed to survive for a very long time. We refer to the fact that, for example, coppersmiths used to sell or repair copper and brass items such as buckets, trays, pots, kettle and others and used to receive for their work 
food, agricultural or household products. Thus 'receiving' has become a habit, learned over many generations:

We do not make buckets because we have not learned how to make them. My father, my uncle and my grandfather made boilers for the people in the village to prepare food for the pigs. They made these items because people in the village used to buy them and use them for breeding animals. Older men still produce such pots and buckets if somebody requests it. Now we breed animals and we sell them. And we are very good at breeding animals because we are used to them since childhood. The woman takes care of the household. These days we go abroad, you know, we go begging for money. The man and the woman go, but together, not separately. (Male, 25, coppersmith, Ighişu Vechi).

My father in-law, although his foot is cut, worked all summer to make buckets. But our men did not learn this craft. We, the young people, we go to Greece in Athens or to Italy in Rome. And we ask for money, we reach out our hand and say: paragalo - please. And if people have money, they give it to you and if they do not have money, they do not give. But nobody humiliates anybody. (Female, 31, coppersmith, Alțâna).

I tell you the truth, young people go to Italy to beg for money. (Male, 66, coppersmith, Brateiu).

Regarding the issues mentioned in this last quote it should be noted that in several villages we were told that young people are abroad, respectively in the villages of Porumbacu de Sus, Alțâna, Ighişu Vechi, in Merghindeal, in Brateiu, and after several meetings and discussions it was confirmed that they are engaged in begging activities.

The only village in which children learn how to make buckets and boilers is Brateiu. Here young boys have a small hammer and an anvil and start to learn to work with sheets of copper or brass. In Brateiu there is also the habit for the coppersmiths to deal in the trade of antiquities. They buy from different individuals all kind of old objects that they also sell. These objects include: furniture, paintings, crockery, cutlery, lamps, boxes, chests, rugs and mats, scales, jewellery and others.

I started this business of selling antiquities a long time ago, almost 15 years ago. There is no old object of some value that had not been in my hands. We go from house to house and we buy from people in villages and towns. But now all the valuable was sold abroad. (Male, 66, coppersmith, Brateiu). 
Traditionally, the woodworkers deal with soft hazel wood, locust, linden, poplar, willow, alder and willow in the manufactured baskets, brooms, crates, pails, forks, spindles, reels, spoons, bowls, chests, trunks, rakes, clothes hangers, cassettes. Our research showed that the younger generation of Roma woodworkers living in rural areas are breeding animals and working the fields.

\section{Conclusion}

We noticed that the traditional Roma family provides a continuing education, for, as Jean-Pierre Liégeois (2008: 65) points out various aspects of social roles are learned at any age. The boy and the young man work beside their father, the girl and the young woman work beside their mother; they each have real responsibilities (for example, commercial responsibilities for the boy, monitoring the little children and preparing food in the absence of the mother for the girl) they learn how to behave with peers, with the opposite sex, as expected by the group with rights and obligations arising from their status. Starting at the age of twelve, children bring an important contribution to their parents' activities, a fact that impacts on their professional and social training in the context of relationships based on mutual respect between children and adults without a cleft existing between theoretical education and apprenticeship roles in the family and economic disciplines.

Regarding the formal education, from the present research we noticed that for Roma, living in urban and rural area, schooling is not particular important. However the attitudes are changing, because they realized that it is very important to know how to read and write.

Regarding the current occupations we can say that, in general, Roma young people develop economic activities that imply some degree of independence. We observe an attitude of rejection towards incomegenerating activities that involve compliance with a fixed schedule, inclusion in a group of colleagues and strict conditions in the workplace. Therefore we consider it to be a feature of the members of this ethnic group that they wish to avoid being someone's employee, or having an ongoing 
relationship with the external environment, an environment that is perceived as being foreign and negative.

\section{References:}

Achim, Viorel. 1998. Tiganii în istoria României. Bucharest: Editura Enciclopedică.

Bădescu, Gabriel, Vlad Grigoraş, Cosima Rughiniş, Mălina Voicu and Ovidiu Voicu. 2007. Barometrul incluziunii rromilor. Bucharest: Fundația pentru o Societate Deschisă.

Banca Monială. 2001. Raport nr.22180-RO: Memorandumul preşedintelui Băncii internaționale pentru reconstrucție şi dezvoltare şi al Corporației financiare internationale adresat directorilor executivi privind Strategia de asistență a grupului băncii mondiale pentru România.

http:/ / www-wds.worldbank.org/external/default/WDSContentServer/ WDSP/IB/2004/05/18/000160016_20040518132958/Rendered/PDF/221800Ro manian0CAS.pdf

Banca Mondială. 2007. Report No.40120-RO, Romania, Poverty Monitoring Analytical and Advisory Assistance Program, First Phase Report, Fiscal Year 2007 Human Development Sector Unit Europe and Central Asia Region.

http:/ / www-wds.worldbank.org/external/default/WDSContentServer/ WDSP/IB/2007/12/04/000020439_20071204114818/Rendered/INDEX/401200 RO.txt

Bădescu, Gabriel, Mircea Kivu and Monica Robotin. 2005. Barometrul relațiilor etnice 1994-2002. O perspectivă asupra climatului interetnic din România. Cluj-Napoca: Editura CRDE.

Burtea, Vasile. 2002. Rromii în sincronia şi diacronia populaților de contact. Bucharest: Editura Lumina Lex.

Cozma, Teodor and Adrian Neculau. 1994. Psihopedagogie - pentru examenul de definitivat şi gradul didactic II. Iaşi: Editura Spiru Haret.

Grigore, Delia. 2001. Curs de antropologie şi folclor rrom: introducere în studiul elementelor de cultură tradițională ale identității contemporane. Bucureşti: Editura Credis.

Institutul de Cercetare a Calității Vieții. 2002. Indicatori privind comunitățile de romi din România. Bucureşti: Editura Expert.

Ilut, Petru. 1997. Abordarea calitativă a socioumanului. Iaşi: Editura Polirom.

Liégeois, Jean-Pierre. 2008. Romii în Europa. Bucureşti: Consiliul Europei.

Moscovici, Serge and Fabrice Buschini. 2007. Metodologia ştiințelor socioumane. Iaşi: Editura Polirom.

Open Society Institute. 2007. Acces egal la educatie de calitate pentru romi. Budapest: Open Society Institute. 
Preda, Marian. 1999. Grupuri sociale ignorate/excluse de politici sociale. In Politici sociale în România (1990-1998), ed. Cătălin Zamfir, 301-342. Bucharest: Editura Expert.

Sandu, Dumitru. 2005. Roma Communities Social Mapping - Targeting by a Community Poverty Survey. Bucharest: C.N.I. Coresi.

Surdu, Laura. 2010. Mecanismele de construcție şi deconstrucție a stigmatizării în cazul romilor din România. Revista Calitatea Vieții 21 (1-2): 51-70.

Văideanu, George. 1988. Educația la frontiera dintre milenii. Bucharest: Editura Politică.

Zamfir, Elena and Cătălin Zamfir. 1993. Țiganii - între ignorare şi îngrijorare Bucharest: Editura Alternative. 